\title{
Does the Flesh Possess Hypostatic Idioms, and If So, Why is it Then Not a Separate Hypostasis?
}

On a Conceptual Problem of Late Patristic Christology

\author{
Dirk Krausmuller \\ Universität Wien, Austria \\ dkrausmuller@hotmail.com
}

\begin{abstract}
This article focuses on a conceptual problem that arose from the application to Christology of the Cappadocian definition of hypostasis as substance with idioms. It discusses the solutions that were proposed by John of Caesarea, Leontius of Byzantium, John Philoponus, Leontius of Byzantium, Maximus the Confessor and John of Damascus.
\end{abstract}

\section{Keywords}

hypostatic idioms - John of Caesarea - Leontius of Byzantium - Leontius of Jerusalem John Philoponus - Maximus the Confessor - John of Damascus

Text

Of the three Christological sects of Late Antiquity only the Nestorians could speak unselfconsciously about a hypostasis of the flesh, which was separate from the hypostasis of the divine Word.* Monophysites and Chalcedonians who put much more emphasis on the oneness of Christ were not willing to accord the flesh such a high degree of independence. Yet they did not find it easy to devise conceptual frameworks that did not result in a 'Nestorian'

* This article is a part of the project "Reassessing Ninth Century Philosophy. A Synchronic Approach to the Logical Traditions" (9 SALT) that has received funding from the European Research Council (ERC) under the European Union's Horizon 2020 research and innovation programme (grant agreement No. 648298). 
Christology. This article shows that there was a lively debate, which continued without interruption from the sixth to the eight century, and that different authors proposed widely differing solutions. In the discussions the hypostatic idioms of the flesh played a central role. The question was: could the flesh have such idioms and nevertheless not be a second hypostasis beside the hypostasis of the divine Word?

In 451 the Council of Chalcedon decreed that Christ's humanity, the flesh, while being a distinct nature, was nevertheless not a separate hypostasis. This qualification was meant to safeguard the unity of the incarnated Word against Nestorian 'divisiveness'. Yet not everybody was convinced that it achieved this aim. The so-called Monophysites objected that if one admitted the existence of two natures one had already jeopardised the oneness of Christ. After several decades of fruitless debates, the Chalcedonians realised that they could only hold their own if they managed to define more clearly what they meant by the terms 'nature' and 'hypostasis'. The first author to undertake this task was the grammarian John of Caesarea. ${ }^{1}$ In his treatise Apologia Concilii Chalcedonensis, which dates to the early years of the sixth century, he adapted for the Christological discourse the conceptual framework that the Cappadocians had developed for the Trinity. ${ }^{2}$ In this framework nature (or substance) was defined as the 'common account of being', the set of properties that is shared by all members of a species. As a universal, it did not have concrete and independent existence, an ontological status that was reserved for hypostasis. ${ }^{3}$ At first sight this seems to be a neat solution to the problem. However, a closer look at John's argument reveals that he did not find it so easy to exclude a 'Nestorian' scenario where the flesh is a second hypostasis beside the hypostasis of the divine Word.

1 On John of Caesarea see A. Grillmeier, Jesus der Christus im Glauben der Kirche. 2/2: Die Kirche von Konstantinopel im 6. Jahrhundert, Freiburg-Basel-Wien, 1989, pp. 54-74.

2 John of Caesarea, Apologia Concilii Chalcedoniensis, ed. M. Richard, M. Aubineau, Iohannis Caesariensis presbyteri et grammatici opera quae supersunt (Corpus Christianorum. Series Graeca, 1), Turnhout-Leuven, 1977, pp. 1-59.

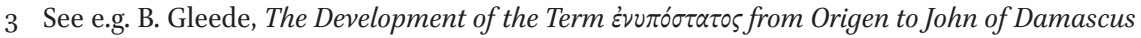
(Supplements to Vigiliae Christianae 113), Leiden-Boston, 2012, 54-55; and J. Zachhuber, "Universals in the Greek Church Fathers," in: Universals in Ancient Philosophy, ed. R. Chiaradonna, G. Galluzzo, Pisa, 2013, pp. 425-470, esp. pp. 456-458. 


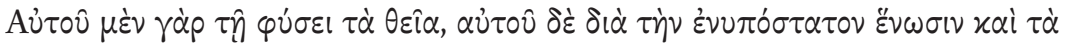

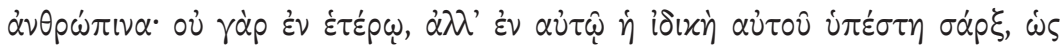

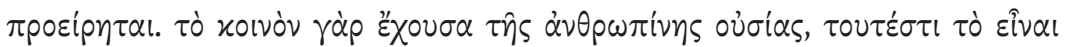

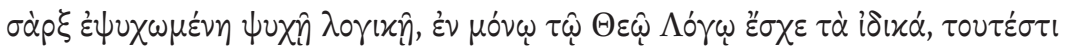

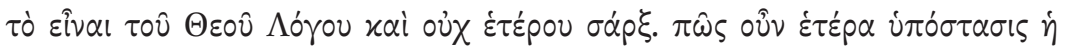
$\mu \eta \delta \dot{\partial} \lambda \omega \varsigma x \alpha \theta^{\prime} \dot{\varepsilon} \alpha u \tau \dot{\eta} \nu \dot{\nu} \pi 0 \sigma \tau \hat{\alpha} \sigma \alpha{ }^{4}$
\end{abstract}

For his is what is divine by nature, and his is also what is human because of the real union. For his own flesh did not gain 'hypostasis' in another but in him, as has been said before. For having the commonality of the human substance, that is to be flesh endowed with a rational soul, it came to have the things that are specific to it in the divine Word alone, that is, to be the flesh of the divine Word and not of another. How then is another hypostasis what did not gain 'hypostasis' by itself?

In this passage John puts forward two arguments. Firstly, he declares that the flesh did not exist prior to its union with the Word but only gained 'hypostasis' within the pre-existing hypostasis of the Word. And secondly, he insists that the flesh only showed the properties that marked out the human species but not $\tau \dot{\alpha} i \delta i x \dot{\alpha}$, that is, the characteristic idioms that would identify it as an individual. The first argument has a long pedigree. As Grillmeier has pointed out, it is already found in the writings of Cyril of Alexandria. ${ }^{5}$ Thus it is not surprising that one also encounters it in Monophysite texts. ${ }^{6}$ By contrast, the second argument addresses a specifically Chalcedonian problem, which arose from the adoption of the Cappadocian conceptual framework. According to this framework, a hypostasis came into existence so-to-speak automatically when characteristic idioms were added to the common nature. ${ }^{7}$ This was a scenario that John had to exclude at all cost. His solution is to deny the flesh all individual features that would have set it apart from other human beings. Such a position is deeply problematic since it reduces the historical Jesus to an abstractum. ${ }^{8}$ Interestingly, John never seems to have considered the possibility that his first argument might be sufficient to rule out the independent existence of the

4 John of Caesarea, Apologia Concilii Chalcedoniensis, IV.3, ed. Richard and Aubineau, p. $55 \cdot 182-188$.

5 Grillmeier, Jesus der Christus, 2/2, pp. 68-69.

6 See Gleede, Development, p. 60.

7 See e.g. Zachhuber, "Universals," p. 467.

8 Grillmeier, Jesus der Christus, 2/2, p. 58. K.-H. Uthemann, "Definitionen und Paradigmen in der Rezeption des Dogmas von Chalkedon bis in die Zeit Kaiser Justinians," in: J. Van Oort, J. Roldanus (eds.), Chalkedon: Geschichte und Aktualität. Studien zur Rezeption der christologischen Formel von Chalkedon, Leuven, 1997, 54-122, argues instead that the flesh has characteristic idioms of its own, but 'in the Word'. This interpretation is not borne out by the text. 
flesh. For him an individualised Jesus would have been a separate hypostasis even if he had come into existence within the hypostasis of the Word.

\section{$3 \quad$ Leontius of Byzantium}

John of Caesarea had formulated his position in response to Monophysite attacks. Yet the Monophysites were not the only group that put pressure on the Chalcedonians. Their conceptual framework was also challenged by the Nestorians. The first Chalcedonian author who reacted to their criticism was Leontius of Byzantium, who flourished in the second quarter of the sixth century. ${ }^{9}$ In his treatise Contra Nestorianos et Eutychianos Leontius lets a Nestorian interlocutor argue that the union of the hypostases of Word and flesh should result in two hypostases since neither of them suffered change. ${ }^{10}$ In his response he complains that the Nestorians do not distinguish properly between nature, which is constituted through the account of being, and hypostasis, which is constituted through characteristic idioms. Then he sets out his own understanding of the incarnation.

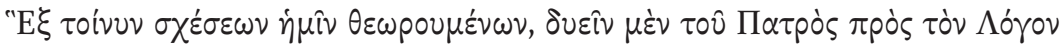

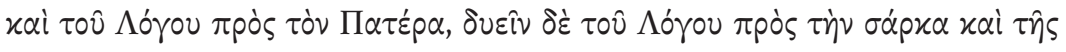

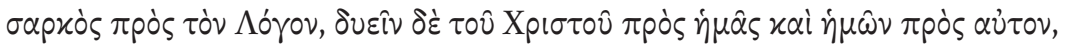

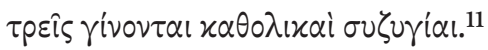

Since six relations are seen by us, two of the Father with the Word and of the Word with the Father, two of the Word with the flesh and of the flesh with the Word, and two of Christ with us and of us with Christ, three universal pairs emerge.

In this passage Leontius makes a clear distinction between the natural and the hypostatic dimensions. The first set of relations is 'horizontal'. The Word and the Father share a common nature but are different hypostases. The second set of relations is 'vertical'. The Word and the flesh share a common hypostasis but

9 On Leontius of Byzantium, see D. Hombergen, The Second Origenist Controversy. A New Perspective on Cyril of Scythopolis' Monastic Biographies as Historical Sources for SixthCentury Origenism, Rome, 2001, pp. 133-138; and B.E. Daley, "A Richer Union: Leontius of Byzantium and the Relationship of Human and Divine in Christ," Studia Patristica, 24 (1993), 239-256.

10 Leontius of Byzantium, Contra Nestorianos et Eutychianos, 4, ed. Brian E. Daley, Leontius of Byzantium. Complete Works, Oxford, 2017, p. 144.9-12.

11 Leontius of Byzantium, Contra Nestorianos et Eutychianos, 4, ed. Daley, p. 146.19-22. 
are different natures. The third set of relations is again 'horizontal'. Accordingly, one would expect Leontius to juxtapose the flesh with all other human beings. This, however, is not the case. Instead, we encounter a telling asymmetry. Leontius replaces the flesh with 'Christ', his term for the being that results from the union of Word and flesh. Such a modification only makes senses if the flesh does not have hypostatic idioms of its own. The distinguishing factor can then only be the characteristic idiom of the Word. At this point we can conclude that Leontius has adopted John of Caesarea's framework. ${ }^{12}$

Yet it seems that he was not entirely happy with this solution. In the immediately following paragraph he declares that the first and the last set of relations are strictly analogous. ${ }^{13}$ This suggests that Leontius would have preferred a symmetrical set of relations in the case of the incarnation as well but refrained from saying so openly, possibly because he feared that he might be accused of having Nestorian leanings. ${ }^{14}$ When he came to write his later treatise Solutiones he had overcome these fears. This is evident from a brief exchange with a Monophysite interlocutor. Leontius lets his adversary ask whether the humanity of Christ was not distinguished from other human beings. ${ }^{15}$ Such a question would have been awkward if Leontius had still adhered to John of Caesarea's point of view. Denying the flesh individual idioms flew in the face of the Biblical accounts about Jesus. Yet acknowledging their existence would have been equally problematic since it would have identified the humanity as a separate hypostasis. Leontius' response shows that he has found an innovative solution, which makes these problems disappear. He accepts that the flesh had individual characteristics, which distinguished it from other beings, but adds an important qualification.

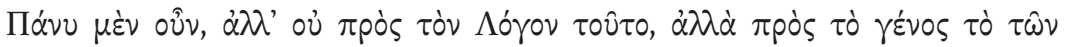

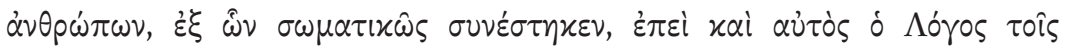

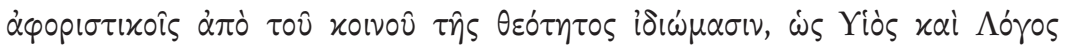

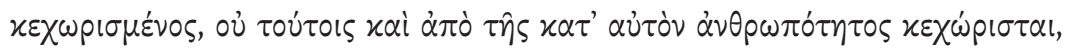

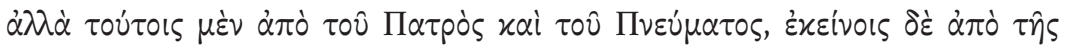

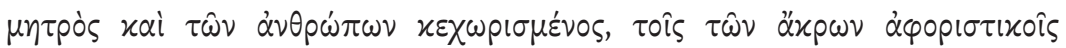

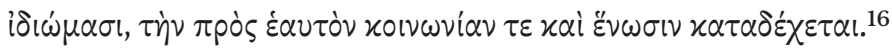

See Grillmeier, Jesus der Christus, 2/2, p. 203. Daley, "Richer Union," pp. 252-253, and S. Otto, Person und Subsistenz. Die philosophische Anthropologie des Leontius von Byzanz, Munich, 1968, p. 36, note the asymmetry but do not discuss its significance.

13 Leontius of Byzantium, Contra Nestorianos et Eutychianos, 4, ed. Daley, 148.1-5.

14 See D. Krausmüller, "A Chalcedonian Conundrum: the Singularity of the Hypostasis of Christ," Scrinium, 10 (2014), pp. 371-391, esp. pp. 372-375.

15 Leontius of Byzantium, Solutiones, ed. Daley, p. 272.13-14.

16 Leontius of Byzantium, Solutiones, ed. Daley, p. 272.15-22. 
Indeed, but not in relation to the Word, but in relation to the human race, from which he was constituted corporeally, since the Word itself, too, which is separated from the commonality of the divinity as Son and Word through separating idioms, is not through these (sc. same separating idioms) also separated from the humanity in him, but being separated through these from the Father and the Spirit, and through those from the mother and the human beings, he receives the communion and union with itself through the separating idioms of the extremes.

In this passage Leontius asserts that hypostatic idioms only distinguish from each other members of the same species. Such a view is a logical consequence of the Cappadocian framework. If two beings do not share the same nature it is impossible to juxtapose their individual characteristics since such characteristics can only be identified through distinction from a common account of being. Thus it would be nonsensical to say that the shape of his nose distinguishes the human being Jesus from the divine Word. More problematic is the positive part of Leontius' argument. He seems to claim that the hypostatic idioms, which distinguish the Word and the flesh from their consubstantial counterparts, somehow effect the union between Word and flesh. This is evidently not the case. At best one can say that they do not preclude such a union.

That Leontius did not shy away from challenging traditional Christological positions is also evident from a later passage in the same treatise.

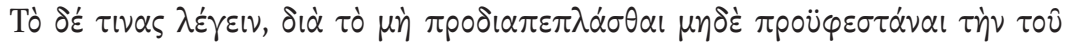

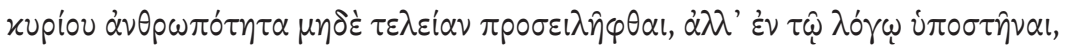

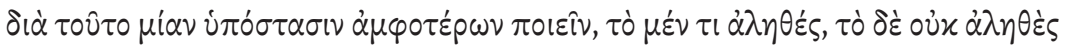

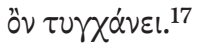

That some say that because the humanity of Christ was not fashioned beforehand nor existed beforehand nor was assumed as a complete (sc. being), but gained 'hypostasis' in the Word, that for this reason there is one hypostasis of both, is partly true and partly not true.

In the following Leontius explains that the flesh did indeed not exist before its union with the divine Word but that one should not therefore think that otherwise the Word could not have united himself with the flesh. He can take this position because of his innovative understanding of hypostasis. According to him a pre-existing flesh would only have been distinguished from other hu- 
man beings but not from the Word and could therefore have been united with the Word in a common hypostasis even if it already had a human hypostasis.

\section{$4 \quad$ John Philoponus}

Significantly, Leontius was not the only author of the time who was prepared to accord the flesh a hypostasis of its own. A similar argument is found in the Christological treatise Arbiter of the philosopher-theologian John Philoponus, which dates to the middle of the sixth century. ${ }^{18}$

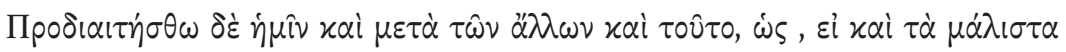

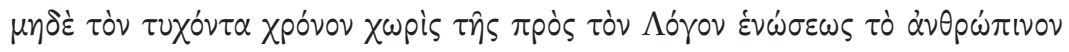

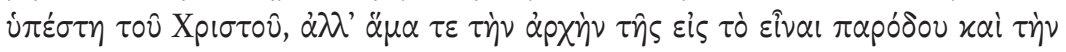

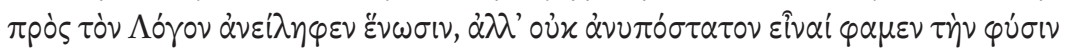

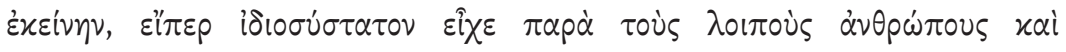

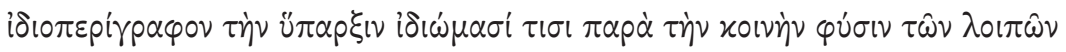

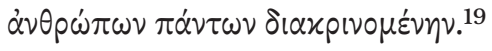

Together with the other points let us also make this preliminary distinction, that, even if the human element of Christ definitely did not gain hypostasis outside the union with the Word even for the smallest amount of time, but assumed the union with the Word simultaneously with the beginning of its coming to be, we nevertheless say that this nature is not without hypostasis, if indeed it had an existence with its own constitution and circumscription beside the other human beings that is separated from all other human beings through some idioms beside the common nature.

Here Philoponus claims that Christ's humanity possessed characteristic idioms, which distinguished it from all other human individuals, and that these idioms constituted a discrete bundle, which was separate from the characteristic idiom of the Word. ${ }^{20}$ Another passage shows how far he is prepared to go.

18 On John Philoponus and his treatise see see U.M. Lang, John Philoponus and the Controversies over Chalcedon in the Sixth Century. A Study and Translation of the Arbiter (Spicilegium Sacrum Lovaniense, 47), Leuven, 2001, pp. 40-41.

19 John Philoponus, Arbiter, ed. F. Diekamp, Doctrina Patrum de Incarnatione Verbi. Ein griechisches Florilegium aus der Wende des siebenten und achten Jahrhunderts, Münster, 1907, p. 280.24-p. 281.1. 


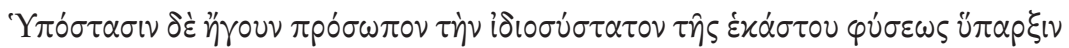

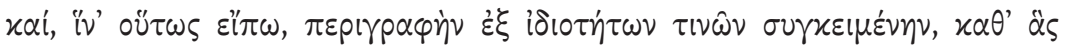

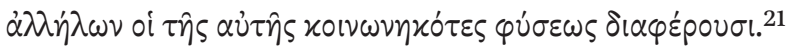

Hypostasis or person (sc. is) the existence with its own constitution of each nature and so-to-speak circumscription composed of properties, according to which (sc. properties) those who share the same nature differ from each other.

This definition leaves no doubt that Philoponus accords to the flesh a hypostasis of its own. He can take this step because he, too, is of the opinion that individual differences can only distinguish consubstantial beings from each other. Such a position should pose no danger to Monophysite Christology. Even if the two sets of hypostatic idioms accede to two distinct bundles of natural properties, the natural properties themselves belong to one single nature so that the unity of the incarnated Word is preserved. Yet it seems unlikely that it would have met with approval from the Monophysite mainstream. Indeed, even Chalcedonian theologians found it too much to stomach. This is evident from a gloss that was added to the text of the Arbiter.

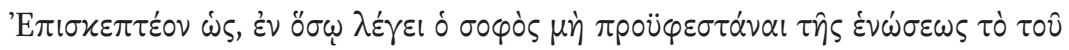

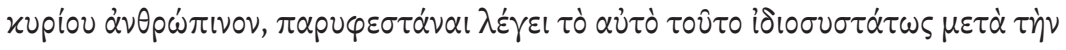

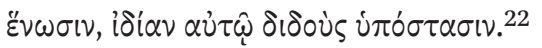

One must observe that, insofar as the sage says that the human (sc. element) of the Lord does not exist prior to the union, he says that this same thing has a hypostasis apart in a self-constituted fashion, giving it a hypostasis of its own.

Here we are back to the framework that had been created by John of Caesarea. Even to claim that the flesh did not exist prior to the union is not sufficient to safeguard the oneness of Christ because the existence of hypostatic idioms would constitute the flesh as a separate hypostasis within the hypostasis of the Word. It is evident that the author of the Chalcedonian gloss would have been even more critical of Leontius of Byzantium who claimed that even the preexistence of the flesh would not endanger the oneness of Christ.

21 John Philoponus, Arbiter, ed. Diekamp, p. 274.10-13.

22 Chalcedonian gloss on the Arbiter, ed. Diekamp, p. 280.1-6. 
How difficult Chalcedonian theologians found it to come up with a satisfactory solution can be seen from the treatise Contra Nestorianos by Leontius of Jerusalem, which dates to the early seventh century. ${ }^{23}$ Leontius quotes arguments from a lost Nestorian treatise that was written only a few years earlier, which he then refutes. One of these arguments reads as follows.

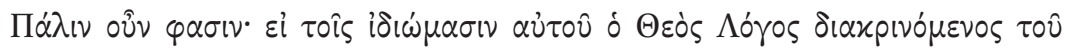

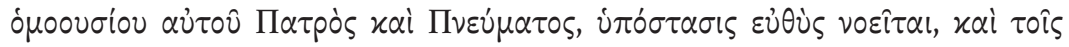

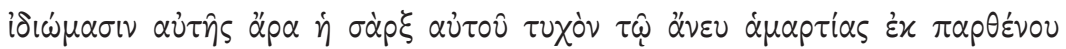

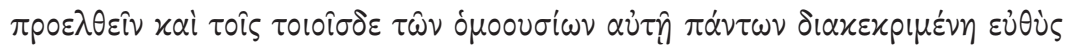
xai

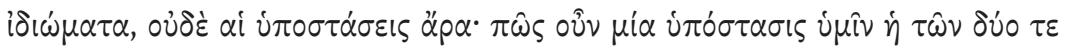

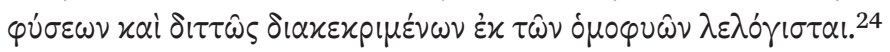

And they say again: If the divine Word when being distinguished through his idioms from his consubstantial Father and Spirit, immediately becomes a hypostasis, then his flesh when being distinguished through his coming forth from the Virgin without sin and similar things from all those that are consubstantial with it, should also be immediately recognised as a hypostasis. Since, then, the idioms of the Word and the flesh are not the same, the hypostases are not (sc. the same) either. How, then can you reckon that there is one hypostasis of two natures that are in a twofold fashion distinguished from those that are consubstantial?

Here we can see how Nestorian polemic had evolved since the early sixth century. Whereas Leontius of Byzantium's adversary had taken it for granted that nature and hypostasis are synonyms, in keeping with traditional Nestorian Christology, Leontius of Jerusalem's opponent takes as his starting point the Cappadocian framework, which had been appropriated by Chalcedonian authors. Thus he can highlight the conceptual problems arising from the Cappadocian definition of hypostasis.

Leontius replies that Christ is a special case because his humanity never existed on its own and that his human idioms can therefore not be considered in separation from the divine Word.

23 On Leontius of Jerusalem see D. Krausmüller, "Leontius of Jerusalem, a theologian of the 7 th century," Journal of Theological Studies, 52 (2001), pp. 637-657.

24 Leontius of Jerusalem, Contra Nestorianos, II.21, $P G, 86,1581 \mathrm{C} 2-12$. 


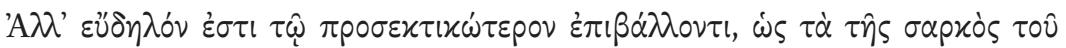

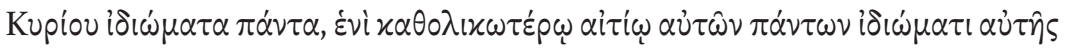

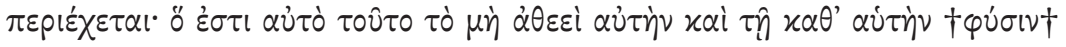

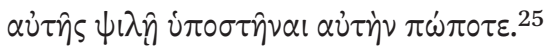

But it is clear to those who consider (sc. the issue) more carefully that all the idioms of the flesh of the Lord are contained in one more universal cause of all its idioms, which is this very thing, not to be without God, and not to have gained hypostasis in a denuded nature by itself.

Leontius accepts the Nestorian claim that the birth of the flesh differed from the birth of other human beings through its sinlessness. Yet he rejects the conclusion that the distinguishing feature 'sinlessness' was a hypostatic idiom proper to the flesh. Instead, he avers that what individualised the flesh accrued to it from the divine Word who was sinless by nature. In a second step he then claims that this rule applies to all aspects of Jesus' life. As Grillmeier has pointed out, this is a highly contrived argument, which leaves no room for specifically human characteristic idioms such as a particular shape of the nose. ${ }^{26}$ Gleede is right when he concludes that this is nothing but a more elaborate version of the argument of John of Caesarea. ${ }^{27}$

Yet this does not mean that Leontius did not make an original contribution to the debate. Elsewhere in the same book he makes another effort to disprove the Nestorian point of view that the flesh is a separate hypostasis. In this case he is prepared to accept that the flesh possesses hypostatic idioms. ${ }^{28}$ This means that he has to show why they do not constitute a hypostasis. His argument reads as follows.

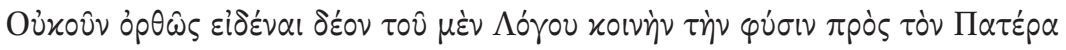

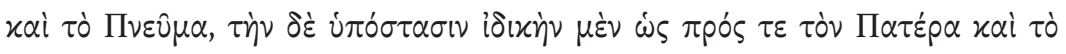

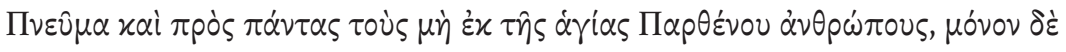

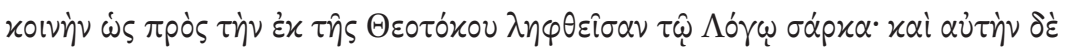

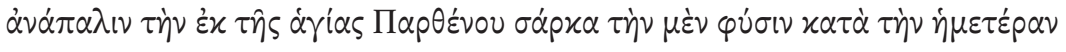

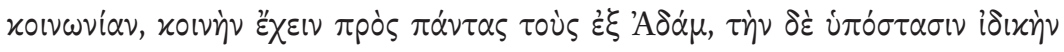

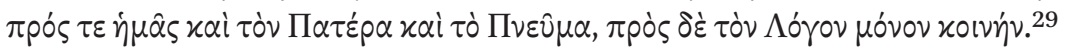

25 Leontius of Jerusalem, Contra Nestorianos, II.21, $P G, 86,1581 \mathrm{C} 20-\mathrm{D} 2$.

26 Grillmeier, Jesus der Christus, 2/2, 314-315; Uthemann, "Definitionen und Paradigmen," p. 113 .

27 Gleede, Development, pp. 136-137.

28 Leontius of Jerusalem, Contra Nestorianos, II.14, $P G, 86,1568 \mathrm{~B} 3-6$.

29 Leontius of Jerusalem, Contra Nestorianos, II.14, PG, 86, 1568B13-C9. 
Therefore one must know correctly that the Word has its nature as a common one in relation to the Father and the Spirit, and its hypostasis as an individual one in relation to the Father and the Spirit and all human beings that are not out of the holy Virgin, and only as a common one in relation to the flesh out of the God-bearer that has been assumed by the Word, and that again the flesh out of the holy Virgin itself has its nature in common with us, common in relation to all those who are out of Adam, and its hypostasis as specific in relation to us and the Father and the Spir$i t$, and only as a common one in relation to the Word.

This tableau resembles closely the conceptual framework that Leontius of Byzantium had set out in his treatise Solutiones. Like his namesake, Leontius of Jerusalem distinguishes between a hypostasis of the Word and a hypostasis of the flesh. There is, however, one crucial difference between the two models. For Leontius of Byzantium the Word is distinguished from Father and Spirit exclusively through the idiom 'generacy' and the flesh is distinguished from other human beings exclusively through characteristics such as a particular shape of the nose. By contrast, Leontius of Jerusalem claims that the human characteristics also distinguish the Word from the Father and the Spirit and that idiom 'generacy' also distinguishes the flesh from other human beings. Otto and Grillmeier have already drawn attention to this idiosyncratic feature of Leontius of Jerusalem's Christology. ${ }^{30}$ However, it has not yet been asked why he felt the need to modify Leontius of Byzantium's Christological model in this fashion. The reason is not difficult to see. Leontius of Jerusalem clearly thought that characteristic idioms also distinguish from each other beings belonging to different natures. For this reason, he could not accept the existence of bounded sets of characteristic idioms. He had to remove the 'firewall' between them and attribute all idioms to the one hypostasis of the incarnated Word. ${ }^{31}$

Leontius was so convinced of the strength of his argument that he even felt he could do without the traditional proviso that the flesh had no separate existence before it was united with the Word.

$30 \quad$ See Grillmeier, Jesus der Christus, 2/2, p. 309. Uthemann, "Definitionen und Paradigmen," 112 , has not recognised this modification. Otto, Person und Subsistenz, 129-130, argues that Leontius of Jerualem elaborated Leontius of Byzantium's conceptual framework, without introducing significant changes.

31 See also Leontius of Jerusalem, Contra Nestorianos, II.14, PG, 86, 1568B13-C9, where we are told that the incarnation is a composition not of two hypostasis but of the elements of two hypostases. Cf. Grillmeier, Jesus der Christus, 2/2, p. 306. 


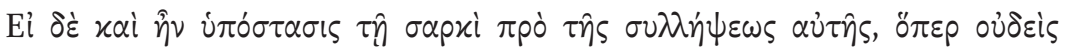

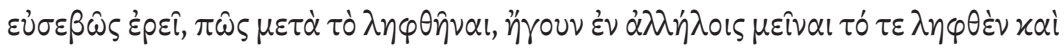

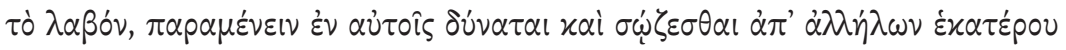

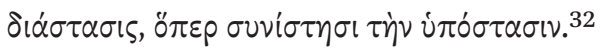

But even if the flesh had possessed a hypostasis before its conception, which no-one will say in a pious fashion, how can after the assumption, that is, after that which is assumed and that which assumes remain in each other, the separation of both from one another, which constitutes the hypostasis, remain and be preserved in them.

The thrust of the argument is clear. The separateness of the flesh disappears because after the union its hypostatic idioms no longer constitute a bounded set and can therefore not be juxtaposed with the hypostatic idiom of the Word.

Leontius' conceptual framework is not entirely without precedent. In the Christological discourse of the fifth century some authors declared that the natural properties of Word and flesh were no longer distinguished but merged with each other so as to constitute one being. ${ }^{33}$ Yet this position was universally rejected because it was believed to confuse the two natures and thus to destroy their integrity. Leontius takes an analogous step when he confuses the two sets of hypostatic idioms. It is doubtful whether such a model can be reconciled with Chalcedonian Christology. The two sets of natural idioms, which remain distinct, seem to lose all function. Here one may discern an affinity with Monoenergism, which paid lip-service to the formula of Chalcedon but put all emphasis on the one hypostatic energy of Christ. ${ }^{34}$

Leontius of Jerusalem was not the only Chalcedonian theologian of the seventh century who discussed the ontological status of the flesh. A few decades later, Maximus the Confessor addressed the same problems. In his Letter 13 he declares that the hypostasis of Christ is one because it is a whole consisting of two parts.

32 Leontius of Jerusalem, Contra Nestorianos, II.14, PG, 86, 1568B8-13.

33 See e.g. A. Grillmeier, Jesus der Christus im Glauben der Kirche, I: Von der Apostolischen Zeit bis zum Konzil von Chalcedon, Freiburg-Basel-Vienna, 1979, pp. 732-733.

34 On this movement see now C. Lange, Mia Energeia. Untersuchungen zur Einigungspolitik des Kaisers Heraclius und des Patriarchen Sergius von Konstantinopel (Studien und Texte zu Antike und Christentum, 66), Tübingen, 2012. 


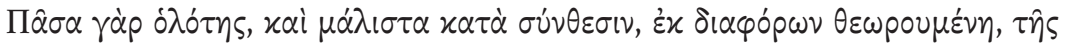

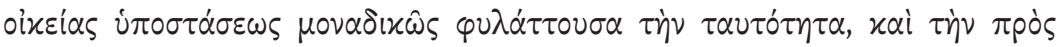

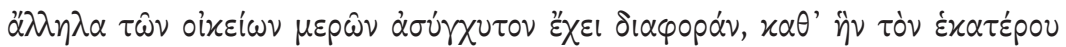

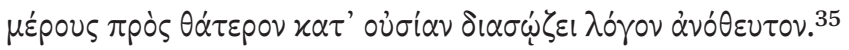

Every whole, and especially when it is seen to be from different (sc. things) according to composition, monadically preserves the identity of its own hypostasis, while having in an unmixed fashion the difference of its own parts from one another, according to which it preserves without adulteration the substantial account of one part as compared with other.

Unfortunately, Maximus does not explain why a 'whole' should not be divisible into its parts. This makes it impossible to assess the value of his argument. Since he accords the flesh hypostatic idioms of its own, which distinguish it from the Virgin, he seems to be in agreement with Leontius of Byzantium. ${ }^{36}$ That he was indeed influenced by Leontius can be seen from his Letter 15 where we read the following.

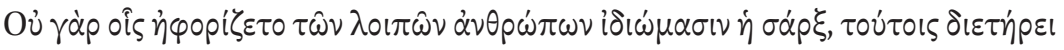

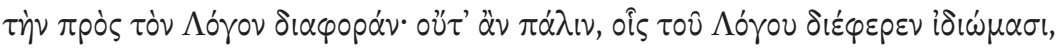

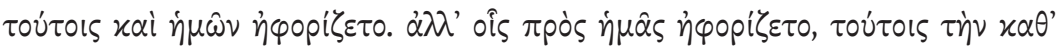

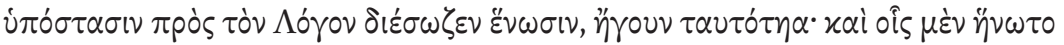

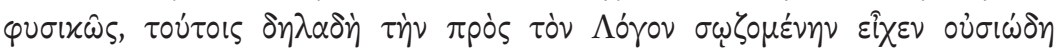
$\delta 1 \alpha \varphi \circ \rho \alpha v^{37}$

For the flesh does not preserve the difference from the Word through the idioms through which it is separated from the other human beings. Nor is it separated from us through the idioms through which it differs from the Word. But it preserves the union, that is, identity, with the Word according to hypostasis through the things through which it is separated from us.

This passage gives the impression that Maximus accepts the thesis that hypostatic idioms distinguish members of the same species but can unite members of different species. ${ }^{38}$ However, even here matters are not so straightforward because Maximus continues in quite a different fashion.

\footnotetext{
35 Maximus the Confessor, Epistula 13, PG, 91, 521C4-9.

36 Maximus the Confessor, Epistula 13, $P G, 91,521 \mathrm{C11}-13$.

37 Maximus the Confessor, Epistula 15, PG, 91, 557A9-B1.

38 Cf. Gleede, Development, p. 155.
} 


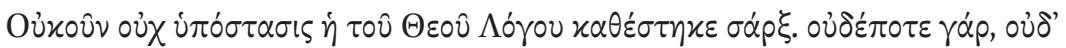

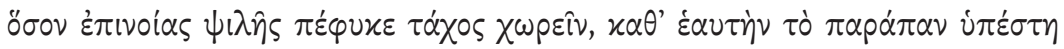

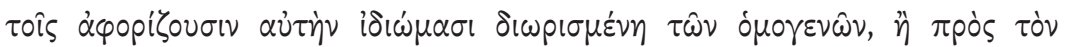

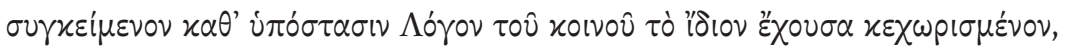

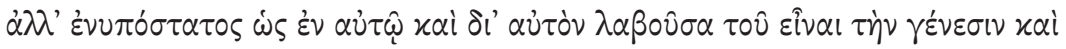

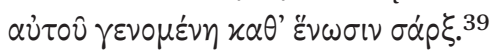

Thus the flesh of the divine Word is not a hypostasis, for it never gained 'hypostasis' by itself at all, even as fast as mere thought is, as being separated from those of the same genus, or as having the proper separated from the common in relation to the Word who is composed < with it $>$ in a hypostasis, but it is insubsistent as having received the coming-to-be in it and because of it and having become his flesh through union.

Here Maximus declares that the flesh did not exist before its union with the Word. Unlike Leontius of Byzantium, however, he regards this not as a mere fact but as a necessary precondition for the oneness of the incarnated Word. He insists that the flesh received its hypostatic idioms only after the union and contends that it was therefore separated neither from other human beings nor from the Word. This latter point is rather unexpected because it gives the impression that the characteristic idioms distinguish the flesh from the Word, a position that would be irreconcilable with Maximus' earlier statement. In any case, it seems doubtful that Maximus' argument would have found universal acceptance. As we have seen, it was widely believed that the presence of hypostatic idioms would turn the flesh into a hypostasis even when the flesh existed within the hypostasis of the Word.

John of Damascus

In his Letter 15 Maximus not only states that the flesh gained 'hypostasis' in the Word but also uses the technical term enhypostaton. In the late Patristic discourse this term has a wide range of meanings. ${ }^{40}$ For Maximus, however, it clearly expresses the notion of insubsistence, that is, the existence of the flesh within the hypostasis of the Word. Insubsistence has been hailed as the

39 Maximus the Confessor, Epistula $15, P G, 91,560 B 11-\mathrm{C}_{3}$.

40 See most recently D. Krausmüller, "Enhypostaton: being 'in another' or being 'with another'? How Chalcedonian theologians of the sixth century defined the ontological status of Christ's human nature," Vigiliae Christianae, 71 (2017), pp. 433-448. 
solution to all conceptual problems surrounding the incarnation. ${ }^{41}$ Yet it is by no means certain that this view is correct. To establish what it can and cannot achieve, we need to turn to John of Damascus. ${ }^{42}$ John's writings are the main source for statements about enhypostaton in the sense of insubsistence, and indeed it is often mentioned by him. Here one example may suffice.

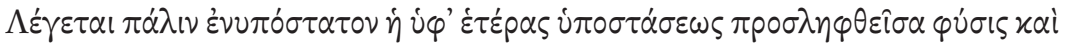

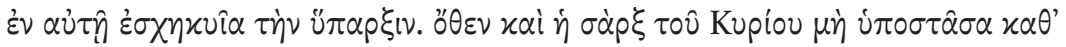

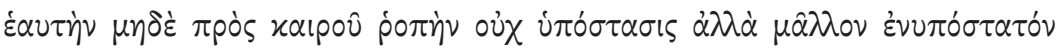

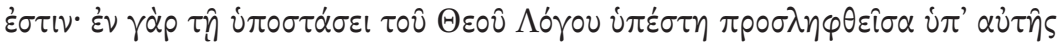

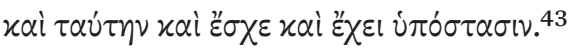

Insubsistent is again called the nature that has been assumed by another hypostasis and has its existence in it. Therefore, the flesh of the Lord, too, which did not subsist by itself not even for a moment, is not a hypostasis but rather insubsistent. For it gained 'hypostasis' (or: came to subsist) in the hypostasis of the divine Word after it had been assumed by it and it has gained it and has it as its hypostasis.

According to the scholarly consensus this should be sufficient in order to make sure that the flesh is not a hypostasis of its own. However, there are clear signs that John of Damascus did not share this opinion. At this point we need to turn to his treatise De duabus in Christo voluntatibus. Before launching into the actual topic, a defence of the two wills, John explains why the incarnated Word is conceptualised as two natures and one hypostasis. He states that a nature is constituted through a distinct set of properties, which distinguishes it from all other natures, and then makes a similar statement about hypostasis. ${ }^{44}$ Here one would have expected John to say that a hypostasis is constituted through a distinct set of characteristic idioms, which distinguish it from all other hypostases. Yet this is not what we find.

41 See K. Rozemond, La Christologie de St. Jean Damascène, Ettal, 1959, p. 22. See also M.U. Lang, "Anhypostatos-Enhypostatos: Church fathers, Protestant orthodoxy and Karl Barth," Journal of Theological Studies, 49 (1998), pp. 630-657, esp. pp. 652-654; Grillmeier, Jesus der Christus, 2/2, 68; and Gleede, Development, 185-186. On John of Damascus see A. Louth, St John Damascene: Tradition and Originality in Byzantine Theology, New York, 2002.

43 John of Damascus, Dialectica. Recensio fusior, 45, ed. B. Kotter, Die Schriften des Johannes von Damaskos, I (Patristische Texte und Studien, 7), Berlin-New York, 1969, p. 110.7-22.

44 John of Damascus, De duabus in Christo voluntatibus, 1, ed. B. Kotter, Die Schriften des Johannes von Damaskos, IV (Patristische Texte und Studien, 22), Berlin-New York, 1981, pp. 173-174.1-6. 


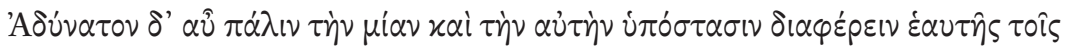

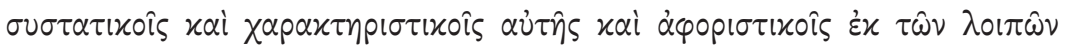

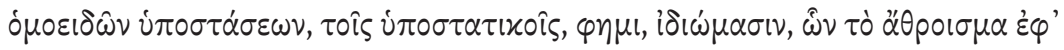

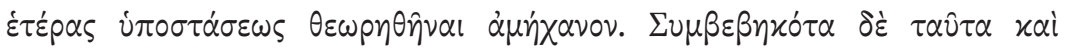

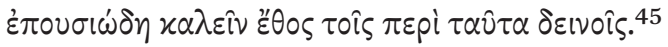

And again the one and the same hypostasis cannot differ from itself through that which is constitutive and characteristic of it and separates it from the other hypostases of the same species, I mean, the hypostatic idioms, the aggregate of which cannot be seen in another hypostasis. These the specialists are wont to call accidents and para-substantial.

Here John states that one and the same hypostasis cannot differ from itself through characteristic idioms. The reason for this statement is, of course, the Christological application. It must be avoided that the human and divine hypostatic idioms divide the one hypostasis into two. The following passages show how John sought to solve this problem. The first point he makes is that hypostases can only be compared with each other within the same species. It would make no sense to compare the baldness of Socrates with the hairiness of Bucephalus because they belong to two different species, 'human being' and 'horse'. One can only compare them by looking at specific differences such as rational and irrational because in this case both fall under the same genus 'animal'. ${ }^{6}$ We have already encountered a similar statement in Leontius of Byzantium. However, John draws a completely different conclusion from it.

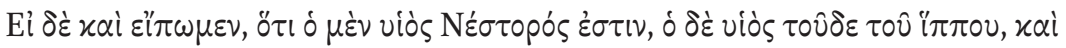

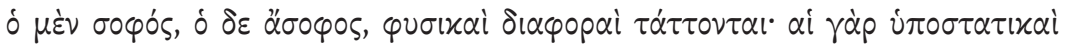

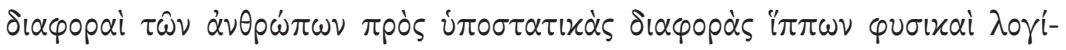

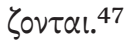

When we say that one is the son of Nestor and the other is the son of this particular horse, and that the one is wise and the other is unwise, natural differences are established. For the hypostatic differences of human beings are reckoned to be natural when compared with the hypostatic differences of horses.

45 John of Damascus, De duabus in Christo voluntatibus, 1, ed. Kotter, IV, p. 173-174.6-11.

46 John of Damascus, De duabus in Christo voluntatibus, 2, ed. Kotter, IV, p. 174.1-10.

47 John of Damascus, De duabus in Christo voluntatibus, 2, ed. Kotter, IV, p. 174.10-14. 
Here John declares that when two beings belonging to two different species are compared, the hypostatic idioms of each of them cannot be distinguished from natural idioms and must therefore be treated as if they were natural idioms. What this means for Christology is then spelt out in the next paragraph.

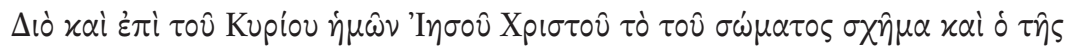

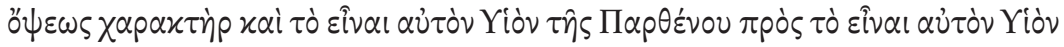

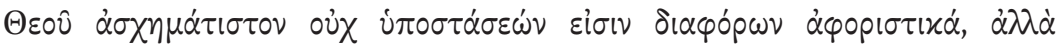

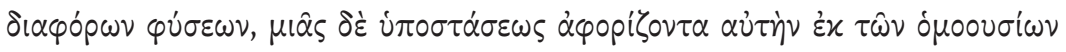

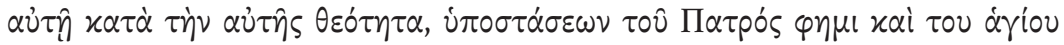

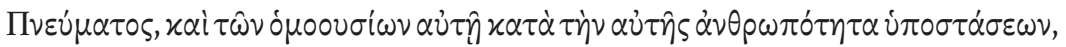

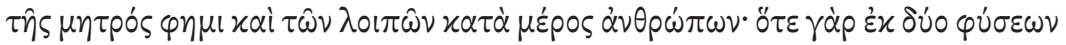

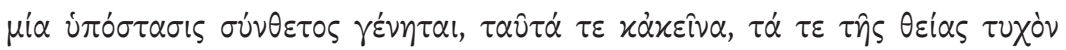

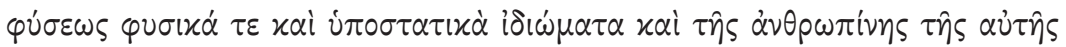
$\dot{v} \pi \circ \sigma \tau \dot{\alpha} \sigma \varepsilon \omega \varsigma \sigma \nu \sigma \tau \alpha \tau i x \dot{\alpha} \gamma\left(v \varepsilon \tau \alpha \mathrm{L} .{ }^{48}\right.$

Therefore also in our Lord Jesus Christ the shape of the body and the expression of the face and the fact that he is the son of the Virgin on the one hand, and the fact that he is the son of God without shape on the other, are not separating different hypostases, but different natures and one hypostasis, separating it (sc. the hypostasis) from those which are consubstantial with it according to its divinity, I mean, from the hypostases of the Father and the Holy Spirit, and from the hypostases that are consubstantial with it according to its humanity, I mean, the mother and the other particular human beings. For when one composite hypostasis comes to be out of two natures, the ones and the others, that is, the natural and hypostatic idioms of the divine and the human natures become constitutive of the same hypostasis.

This is an ingenious solution to the Christological problem. Once hypostatic idioms are rebranded as natural idioms all problems disappear since the existence of two natures is accepted in Chalcedonian Christology. That John takes the trouble to devise such a conceptual framework is highly significant. It shows that insubsistence alone was not enough to make sure that the flesh was not a hypostasis of its own.

48 John of Damascus, De duabus in Christo voluntatibus, 2, ed. Kotter, IV, pp. 175-176.15-25. 
The hypostatic idioms of the flesh posed a serious problem for Chalcedonian theologians of the sixth to eighth centuries. According to the Cappadocian framework, which they regarded as valid not only for Trinitarian theology but also for Christology, the addition of such idioms to the common nature automatically constituted a hypostasis. This gave the impression as if the flesh were a second separate hypostasis beside the divine Word. The first author to propose a solution was the grammarian John of Caesarea. Like other authors before him, John insisted that the flesh did not exist prior to the union with the Word. Yet he realised that this argument was not sufficient because the hypostatic idioms would have turned the flesh into a hypostasis even when it existed in the divine Word. Therefore, he claimed that the flesh did not have any hypostatic idioms. This explanation, however, had a drawback. It gave the impression that the flesh was a mere abstraction. A more satisfactory treatment of the topic was offered by Leontius of Byzantium. Leontius pointed out that two beings can only be distinguished from one another through hypostatic idioms when they belong to the same species because hypostatic idioms can only be identified where the account of being is common. Therefore, he concluded that the hypostatic idioms of the flesh distinguished it from other human beings but not from the divine Word. As a consequence, he even considered it possible that the flesh existed prior to its union with the Word. The Monophysite John Philoponus held a similar view, although he rejected preexistence. Yet these were exceptional cases. Most theologians shared John of Caesarea's position. Leontius of Jerusalem offered two mutually exclusive explanations. In one section of his text he denied that the flesh had hypostatic idioms. In another section he acknowledged their existence, but declared that they did not constitute a bounded set but were commingled with the hypostatic idiom of the Word and thus did not distinguish Word and flesh from one another. Maximus' contribution to the debate is less impressive. In the same text he combined the approaches of Leontius of Byzantium and of John of Caesarea, seemingly unaware of the fact that they were irreconcilable. More interesting is John of Damascus who started from the same observations as Leontius of Byzantium but arrived at a different conclusion. He declared that when one compares two beings belonging to different species one must treat the hypostatic idioms as if they were natural idioms. Thus he could conclude that the hypostatic idioms not distinguish Word and flesh as hypostases. Significantly, he felt the need to develop this explanation despite his use of the concept of insubsistence. This shows clearly that insubsistence alone was not considered to be a solution to all conceptual problems. 